\title{
Influence of salicylate administration on weight gain and serum biochemical parameters in broiler chickens
}

\author{
BŁAŻEJ POŹNIAK*, YUAN HUI, YI JINE, GUO CHENGZHI, DENG SIJUN, \\ ZHU LI, LU YIN, YANG YANG, MARCIN ŚWITAŁA*
}

\begin{abstract}
Veterinary College, Hunan Agricultural University, Furong District Changsha City, Hunan, P. R. China 410128
*Department of Biochemistry, Pharmacology, and Toxicology, Faculty of Veterinary Medicine, Wroclaw University of Environmental and Life Sciences, Norwida 31, 50-375 Wrocław
\end{abstract}

\section{Poźniak B., Yuan H., Yi J., Guo C., Deng S., Zhu L., Lu Y., Yang Y., Świtała M. Influence of salicylate administration on weight gain and serum biochemical parameters in broiler chickens}

\section{Summary}

The aim of the study was to investigate the effects of different doses of acetylsalicylic acid (ASA) and sodium salicylate (SS) administration on weight gains and serum biochemical parameters in broiler chickens. This study was performed to investigate the safety of ASA and SS in chickens in conditions of moderate overdose. Seventy five broiler chickens (Sanhuangji breed) were divided into control and experimental groups. The chickens were administered orally with ASA or SS in the following daily doses: 50,100 and $200 \mathrm{mg} / \mathrm{kg}$ for 20 days. In the course of the experiment weight gains were recorded. On day 14 and day 20 the chickens were sampled for blood biochemical analysis. Investigated parameters included serum total protein, albumin, uric acid, creatinine, potassium, sodium and calcium contents as well as alanine transaminase activity. After the last samplings the chickens were dissected and liver and kidney to body weight ratios were recorded. It was demonstrated that SS at a dose of $200 \mathrm{mg} / \mathrm{kg}$ increased serum total protein level. ASA increased serum proteins at a dose of $100 \mathrm{mg} / \mathrm{kg}$ but not at a higher dose. At the dose of $200 \mathrm{mg} / \mathrm{kg} \mathrm{ASA}$ increased the kidney to body weight ratio. In all salicylate treated groups the liver weights were lower as compared to the control. No clinical manifestations of intolerance were observed. It is assumed that chickens tolerate ASA and SS well, even in doses producing distinct side effects in several mammalian species.

Keywords: acetylsalicylic acid, sodium salicylate, weight gain, serum biochemistry, chickens

Salicylates belong to the oldest known non-steroid anti-inflammatory drugs (NSAIDs). In veterinary medicine they are applied due to their anti-inflammatory and analgesic properties $(3,17)$. In bird medicine, the most frequently used salicylates are acetylsalicylic acid (ASA) and sodium salicylate (SS). Although modern and safer drugs have been developed, salicylates are still in use, as they are cheap and easy to administer in medicated feed or water. The economical factor is especially important in treating livestock and poultry. European regulations concerning salicylates in poultry medicine have only been issued in recent years. The European Agency for the Evaluation of Medicinal Products (EMEA) accepted the oral administration of ASA in chickens in 2003 (summary report EMEA/MRL/860/03) and oral SS administration in turkeys in 2007 (summary opinion EMEA/CVMP/ 561036/2007). In January 2010, EMEA issued a mean residue level (MRL) values for SS in turkeys (summary opinion EMEA/CVMP/16267/2010). This indicates that salicylates are still objects of research and scientific concern. Several indications for use of salicylates and other NSAIDs in birds have been proposed by different authors. These include trauma, intestinal imbalance due to coccidial and bacterial diseases, sudden death syndrome, broiler ascites, heat stress, promotion of growth and egg production $(6,7$, $9-11,14,18,20,24,26,27)$. Whereas the benefits of anti-inflammatory drugs usage in locomotion disturbances or trauma are well documented $(10,14,20)$, some other indications seem to be contradictory and empirical (3). Several studies carried out in recent years have been focused on pharmacokinetics of SS in poultry $(3,4)$ and its efficacy in inflammation models in birds $(5,13)$, but well documented data on the tolerance and specific side effects of these drugs in birds 
seems to be insufficient. The general mechanism of action of NSAIDs is the inhibition of cyclooxygenase (COX), enzyme responsible for converting arachidonic acid into prostanoids - important local hormones and mediators of inflammation. There are two isoforms of COX, both having different physiological function. COX1 is responsible for constitutive prostaglandin synthesis in, for example, haemostasis, protection of gastro-intestinal mucous membranes and maintaining renal blood flow (8), whereas the inducible COX2 synthesizes prostaglandins during inflammatory processes. Since most NSAIDs inhibit both COX1 and $\mathrm{COX} 2$, the drug's safety is usually associated with the relative degree to which they inhibit respective isoforms. It is generally accepted that salicylates are preferential COX1 inhibitors. Adverse effects associated with salicylates are mainly due to the impairment of constitutive prostaglandin synthesis (8). Most frequently affected targets are gastro-intestinal tract, haemostasis, kidneys and electrolyte homeostasis. Since salicylates (as well as other NSAIDs) show strong inter-species variability in their safety of usage, the results obtained for one species cannot be extrapolated to another.

The aim of the study was to investigate the effects of different doses of ASA and SS administration on weight gains and serum biochemical parameters in broiler chickens. Besides live body weight measurements, liver and kidney to body weight ratios were recorded, whereas several serum biochemical parameters served as the early markers of potential intolerance to the administered drugs.

\section{Material and methods}

Seventy five young healthy female broiler chickens (Sanhuangji breed, 40-day-old, approx. $1 \mathrm{~kg}$ ) were obtained from a commercial farm (Hunan, China) and divided into 7 groups (10 or 11 individuals each). The animals were kept in cages and fed a commercial broiler chicken feed along with tap water ad libitum. The groups SS 50, SS 100, SS 200, ASA 50, ASA 100, and ASA 200 were treated with SS or ASA at doses of 50,100 and $200 \mathrm{mg} / \mathrm{kg}$ respectively. The drugs were dissolved (SS) or suspended (ASA) ex tempore in starch gel to obtain final concentrations of 50, 100 and $200 \mathrm{mg} / \mathrm{mL}$ and then administered individually once a day via a tube into the crop at an appropriate volume $(1 \mathrm{~mL} /$ $\mathrm{kg}$ ). The control group was given an appropriate volume of starch gel. The chickens were fed approximately $30 \mathrm{~min}$ after the drug administration. The whole treatment lasted 20 days. The body weight was noted regularly. On days 14 and 20 blood was sampled $(5 \mathrm{~mL})$ by brachial venipuncture and collected into single-use tubes for clotting. Blood serum was separated by centrifugation (3000 rpm, $15 \mathrm{~min}$ ) and the samples were stored at $-20^{\circ} \mathrm{C}$ until assayed. After the last sampling, 5 birds from each group were sacrificed by rapid decapitation and subjected to necroscopic examination. Liver and kidney weights were recorded and samples for histological investigation (haematoxylin and eosin staining) were stored in $4 \%$ formalin. Liver and kidney weights to body weights ratios (liver and kidney indices) were expressed as body weight percent. The use and care of animals were in accordance with the guideline of the Hunan Agricultural University in Changsha, China, where the study was carried out. The Polish co-authors obtained permission from the Local Ethical Committee to carry out an identical experiment in Poland.

ASA was obtained from Sinopharm Chemical Reagent Co., Ltd (Shanghai, China) and SS from Jinan Trading Limited Animal Husbandry and Culture Park (Jinan, Shandong, China). Kits for determination of alanine transaminase (ALT) activity and measurements of uric acid, creatinine, total protein, albumin and calcium contents were obtained from Biosino Bio-technology \& Science Inc. (Beijing, China) and the estimates were performed with the Mindray BS-200 Chemistry Analyser (Shenzhen, China). The contents of sodium and potassium were measured manually using kits obtained from Nanjing Jiancheng Bioengineering Institute (Nanjing, China). All estimates were performed according to the manufacturer's instructions.

Experimental data were expressed as the mean and standard deviation. Student's unpaired t-test was used to identify significant differences between the control and each of the experimental groups.

\section{Results and discussion}

During treatment the chickens did not show any clinical signs of intolerance, nor was the feed or water uptake visibly affected. The weight gains in different groups measured at day 10 and 20 respectively were summarised in fig 1. A significant increase in weight gain was observed in the group SS $100(p<0.01)$ as compared to the control group. Weight gain in the group SS 200 was lower than in the control group but it did not show statistical significance. In the ASA treated groups no significant influence on weight gain was observed. No macroscopic lesions were found. Liver and kidney indices are summarised in fig 2 . The highest kidney indices were observed in groups ASA 200 and SS 200 but as compared to the control group, these results show statistical significance only for ASA $(\mathrm{p}<0.01)$. Histological evaluation did not reveal any lesions. Liver indices were lower in all experimental groups treated with either ASA or SS. In SS treated groups the decrease was significant in all three groups but chickens from SS 100 had the lowest liver indices $(p<0.01)$. In ASA treated groups the decrease was found to be statistically significant $(\mathrm{p}<0.01)$ only in the groups ASA 50 and ASA 100. No lesions were found microscopically in livers in either the ASA or SS treated groups.

Blood parameters measured at day 14 and day 20 are summarised in table 1 . The serum ALT activity and creatinine, potassium, sodium and calcium contents did not significantly differ between experimental groups. The level of uric acid was slightly increased in the group ASA 200 as compared to the control group $(\mathrm{p}<0.01)$ but it remained within the physiological range (19). Total serum protein content showed a statistically significant increase in group SS 200 on days 
Tab. 1. Mean (M) and standard deviation (SD) values of serum biochemical parameters obtained after 14 and 20 days of treatment

\begin{tabular}{|c|c|c|c|c|c|c|c|c|c|c|c|c|c|c|c|}
\hline \multirow{3}{*}{ Parameter } & \multirow{3}{*}{ n } & \multicolumn{7}{|c|}{ Day 14} & \multicolumn{7}{|c|}{ Day 20} \\
\hline & & & $\begin{array}{l}\text { SS } \\
50\end{array}$ & $\begin{array}{c}\text { SS } \\
100\end{array}$ & $\begin{array}{l}\text { SS } \\
200\end{array}$ & $\begin{array}{c}\text { ASA } \\
50\end{array}$ & $\begin{array}{l}\text { ASA } \\
100\end{array}$ & $\begin{array}{l}\text { ASA } \\
200\end{array}$ & control & $\begin{array}{l}\text { SS } \\
50\end{array}$ & $\begin{array}{c}\text { SS } \\
100\end{array}$ & $\begin{array}{c}\text { SS } \\
200\end{array}$ & $\begin{array}{c}\text { ASA } \\
50\end{array}$ & $\begin{array}{l}\text { ASA } \\
100\end{array}$ & $\begin{array}{l}\text { ASA } \\
200\end{array}$ \\
\hline & & 11 & 11 & 10 & 11 & 11 & 10 & 11 & 11 & 11 & 10 & 11 & 11 & 10 & 11 \\
\hline $\begin{array}{l}\text { ALT } \\
{[u / L]}\end{array}$ & $\begin{array}{l}M \\
S D\end{array}$ & $\begin{array}{c}45.9 \\
\pm 12.2\end{array}$ & $\begin{array}{r}49.6 \\
\pm 9.8\end{array}$ & $\begin{array}{c}51.1 \\
\pm 19.4\end{array}$ & $\begin{array}{c}32.5 \\
\pm 17.5\end{array}$ & $\begin{array}{r}30.7 \\
\pm 9.4\end{array}$ & $\begin{array}{c}40.2 \\
\pm 13.9\end{array}$ & $\begin{array}{c}41.8 \\
\pm 10.3\end{array}$ & $\begin{array}{c}66.1 \\
\pm 17.6\end{array}$ & $\begin{array}{c}46.7 \\
\pm 30.3\end{array}$ & $\begin{array}{c}62.9 \\
\pm 23.1\end{array}$ & $\begin{array}{r}58.6 \\
\pm 22.5\end{array}$ & $\begin{array}{c}44.5 \\
\pm 17.7\end{array}$ & $\begin{array}{c}58.8 \\
\pm 12.3\end{array}$ & $\begin{array}{c}62.6 \\
\pm 14.7\end{array}$ \\
\hline $\begin{array}{l}\text { Total protein } \\
\text { [g/L] }\end{array}$ & $\begin{array}{l}M \\
S D\end{array}$ & $\begin{array}{r}41.1 \\
\pm 3.2\end{array}$ & $\begin{array}{r}45.9 \\
\pm 5.7\end{array}$ & $\begin{array}{r}43.6 \\
\pm 3.5\end{array}$ & $\begin{array}{l}47.7^{*} \\
\pm 7.0\end{array}$ & $\begin{array}{l}43.1 \\
\pm 5.1\end{array}$ & $\begin{array}{l}52.8^{*} \\
\pm 10.3\end{array}$ & $\begin{array}{r}45.7 \\
\pm 6.9\end{array}$ & $\begin{array}{r}42.3 \\
\pm 2.0\end{array}$ & $\begin{array}{l}41.7 \\
\pm 3.7\end{array}$ & $\begin{array}{r}42.3 \\
\pm 3.2\end{array}$ & $\begin{array}{l}46.0^{*} \\
\pm 4.4\end{array}$ & $\begin{array}{l}39.4 \\
\pm 4.1\end{array}$ & $\begin{array}{l}51.6^{*} \\
\pm 8.8\end{array}$ & $\begin{array}{l}43.1 \\
\pm 6.1\end{array}$ \\
\hline $\begin{array}{l}\text { Albumin } \\
\text { [g/L] }\end{array}$ & $\begin{array}{l}M \\
S D\end{array}$ & $\begin{array}{r}15.2 \\
\pm 1.8\end{array}$ & $\begin{array}{r}16.6 \\
\pm 1.9\end{array}$ & $\begin{array}{r}17.0 \\
\pm 1.5\end{array}$ & $\begin{array}{r}16.6 \\
\pm 2.4\end{array}$ & $\begin{array}{r}15.5 \\
\pm 1.8\end{array}$ & $\begin{array}{l}17.5^{*} \\
\pm 1.4\end{array}$ & $\begin{array}{r}16.0 \\
\pm 2.5\end{array}$ & $\begin{array}{r}17.3 \\
\pm 1.4\end{array}$ & $\begin{array}{l}17.2 \\
\pm 2.1\end{array}$ & $\begin{array}{r}17.1 \\
\pm 1.7\end{array}$ & $\begin{array}{r}18.7 \\
\pm 2.5\end{array}$ & $\begin{array}{r}16.6 \\
\pm 1.2\end{array}$ & $\begin{array}{l}19.8^{*} \\
\pm 1.9\end{array}$ & $\begin{array}{r}18.0 \\
\pm 2.7\end{array}$ \\
\hline $\begin{array}{l}\text { Sodium } \\
\text { [mmol/L] }\end{array}$ & $\begin{array}{l}M \\
\text { SD }\end{array}$ & $\begin{array}{r}143.0 \\
\pm 12.3\end{array}$ & $\begin{array}{r}134.1 \\
\pm 23.2\end{array}$ & $\begin{array}{r}136.9 \\
\pm 14.4\end{array}$ & $\begin{array}{r}144.8 \\
\pm 10.8\end{array}$ & $\begin{array}{l}133.6 \\
\pm 7.6\end{array}$ & $\begin{array}{l}144.2 \\
\pm 4.8\end{array}$ & $\begin{array}{l}132.1 \\
\pm 8.0\end{array}$ & $\begin{array}{r}127.6 \\
\pm 14.4\end{array}$ & $\begin{array}{r}123.2 \\
\pm 20.8\end{array}$ & $\begin{array}{r}133.0 \\
\pm 11.1\end{array}$ & $\begin{array}{l}129.5 \\
\pm 6.0\end{array}$ & $\begin{array}{r}117.5 \\
\pm 18.8\end{array}$ & $\begin{array}{l}121.1 \\
\pm 8.8\end{array}$ & $\begin{array}{r}132.1 \\
\pm 14.7\end{array}$ \\
\hline $\begin{array}{l}\text { Kalium } \\
\text { [mmol/L] }\end{array}$ & $\begin{array}{l}M \\
\text { SD }\end{array}$ & $\begin{array}{c}6.0 \\
\pm 0.6\end{array}$ & $\begin{array}{c}5.8 \\
\pm 0.5\end{array}$ & $\begin{array}{r}5.8 \\
\pm 0.5\end{array}$ & $\begin{array}{c}5.7 \\
\pm 0.7\end{array}$ & $\begin{array}{c}5.4 \\
\pm 0.5\end{array}$ & $\begin{array}{c}5.7 \\
\pm 0.6\end{array}$ & $\begin{array}{c}5.3 \\
\pm 0.6\end{array}$ & $\begin{array}{c}5.1 \\
\pm 0.6\end{array}$ & $\begin{array}{c}5.2 \\
\pm 0.7\end{array}$ & $\begin{array}{r}5.8 \\
\pm 0.7\end{array}$ & $\begin{array}{c}5.3 \\
\pm 0.5\end{array}$ & $\begin{array}{c}5.1 \\
\pm 0.6\end{array}$ & $\begin{array}{c}5.9 \\
\pm 1.1\end{array}$ & $\begin{array}{c}6.0 \\
\pm 1.3\end{array}$ \\
\hline $\begin{array}{l}\text { Calcium } \\
\text { [mmol/L] }\end{array}$ & $\begin{array}{l}M \\
\text { SD }\end{array}$ & $\begin{array}{c}3.7 \\
\pm 0.7\end{array}$ & $\begin{array}{c}4.0 \\
\pm 0.7\end{array}$ & $\begin{array}{c}3.6 \\
\pm 0.6\end{array}$ & $\begin{array}{c}3.7 \\
\pm 0.8\end{array}$ & $\begin{array}{c}3.5 \\
\pm 0.9\end{array}$ & $\begin{array}{c}3.3 \\
\pm 0.6\end{array}$ & $\begin{array}{c}3.7 \\
\pm 8.5\end{array}$ & $\begin{array}{c}3.7 \\
\pm 0.9\end{array}$ & $\begin{array}{c}4.0 \\
\pm 0.7\end{array}$ & $\begin{array}{c}4.0 \\
\pm 0.8\end{array}$ & $\begin{array}{c}4.1 \\
\pm 0.5\end{array}$ & $\begin{array}{c}3.4 \\
\pm 0.8\end{array}$ & $\begin{array}{c}3.9 \\
\pm 0.9\end{array}$ & $\begin{array}{c}4.1 \\
\pm 0.9\end{array}$ \\
\hline $\begin{array}{l}\text { Uric acid } \\
\text { [بmol/L] }\end{array}$ & $\begin{array}{l}M \\
\text { SD }\end{array}$ & & & & na & & & & $\begin{array}{l}361.1 \\
\pm 9.0\end{array}$ & $\begin{array}{r}365.3 \\
\pm 11.4\end{array}$ & $\begin{array}{l}363.1 \\
\pm 7.9\end{array}$ & $\begin{array}{r}366.3 \\
\pm 13.1\end{array}$ & $\begin{array}{l}354.7 \\
\pm 2.8\end{array}$ & $\begin{array}{l}363.1 \\
\pm 6.4\end{array}$ & $\begin{array}{l}386.6^{*} \\
\pm 17.6\end{array}$ \\
\hline $\begin{array}{l}\text { Creatinine } \\
\text { [ } \mu \mathrm{mol} / \mathrm{L}]\end{array}$ & $\begin{array}{l}M \\
\text { SD }\end{array}$ & & & & na & & & & $\begin{array}{r}206.1 \\
\pm 25.6\end{array}$ & $\begin{array}{r}215.8 \\
\pm 26.5\end{array}$ & $\begin{array}{r}207.6 \\
\pm 45.2\end{array}$ & $\begin{array}{r}191.0 \\
\pm 26.8\end{array}$ & $\begin{array}{r}192.6 \\
\pm 25.4\end{array}$ & $\begin{array}{r}204.9 \\
\pm 13.7\end{array}$ & $\begin{array}{l}203.9 \\
\pm 34.1\end{array}$ \\
\hline
\end{tabular}

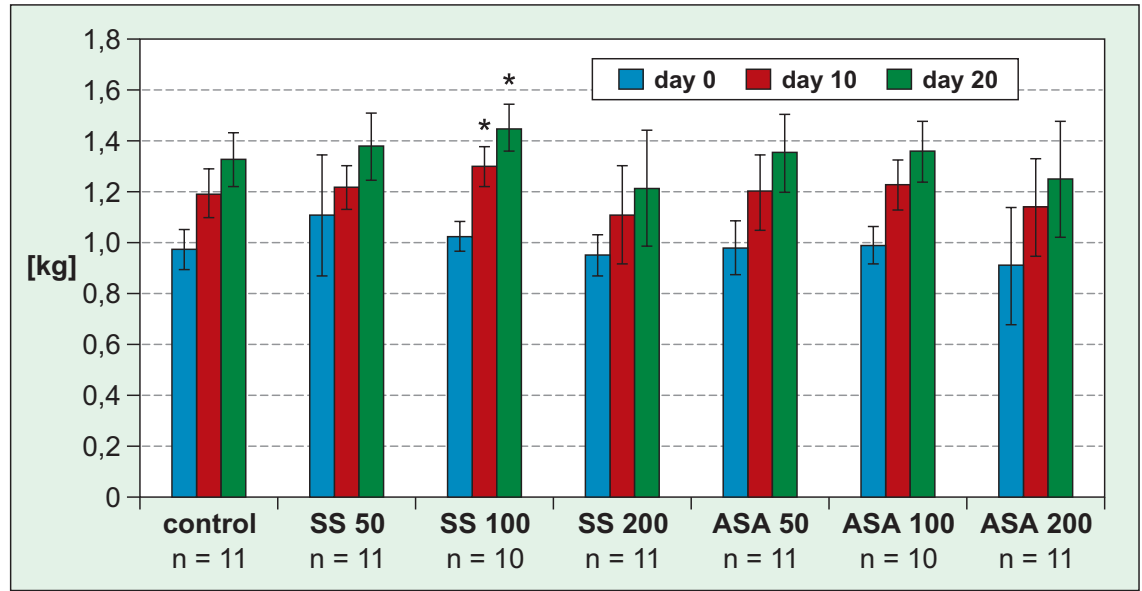

Fig. 1. Weight gains in chickens treated with sodium salicylate (SS) and acetylsalicylic acid (ASA) measured at days 10 and 20

Explanations: * statistically significant difference $(\mathrm{p}<0.05)$ as compared to control group

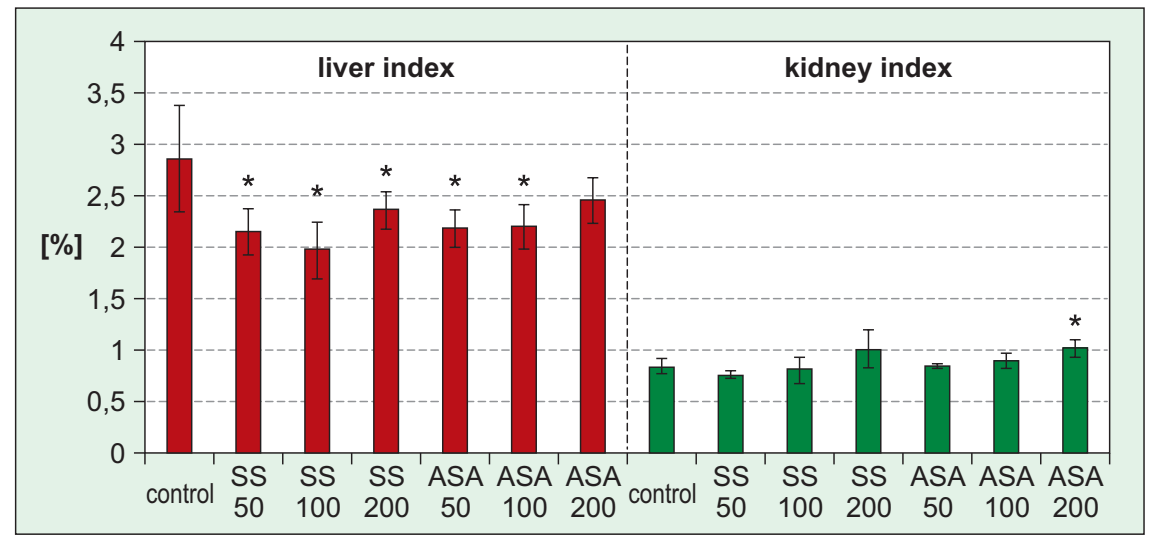

Fig. 2. Liver and kidney weight to body weight indices (\%) in chickens treated with sodium salicylate (SS) and acetylsalicylic acid (ASA)

Explanations: statistically significant difference $(\mathrm{p}<0.05)$ as compared to control group ( $=5$ in each group)
Explanations: $*$ statistically significant differences at $\mathrm{p}<0.05$ as compared to control group; $\mathrm{n}$ - number of animals in the group; ALT - alanine transaminase; na - not analyzed

14 and 20 ( $\mathrm{p}<0.05$ in both cases). In the ASA treated animals a statistically significant increase in total serum protein content was observed in the group ASA $100(\mathrm{p}<0.01)$ but not at a higher dose. This was observed in both measurements (day 14 and day 20). The level of serum albumins did not show any significant differences in SS treated groups as compared to the control. In ASA treated groups the pattern of albumin levels was similar to total protein levels. Only in the group ASA 100 a significant $(\mathrm{p}<0.01)$ increase in serum albumin was found.

The purpose of this study was not to cause salicylate poisoning, but to investigate the ability of chickens to tolerate a moderate ASA and SS overdose. In many scientific papers investigating the effect of ASA or SS treatment in animals the applied dose is expressed as a percent of feed or water volume. We found this not accurate enough as both water and feed uptake may vary among individuals especially when side effects appear. This is why we decided to dose the drugs individually. The lowest dose for both drugs applied in this study $(50 \mathrm{mg} / \mathrm{kg})$ was based on data obtained from empirical use and 
kinetic studies in chickens (4). Usually the treatment lasts about 5 days. To reproduce the conditions of moderate overdose the experimental protocol included groups treated with doses increased 2 and 4 times (100 and $200 \mathrm{mg} / \mathrm{kg}$ respectively) and the total time of treatment was extended to $20 \mathrm{~d}$.

During the experiment chickens did not show any clinical signs of intolerance to the administered drugs. In SS treated chickens, a significant increase in weight gain was observed only in SS 100 . This effect was dose independent and was not reproduced in the ASA treated groups. Therefore, we conclude that although beneficial influence of SS on weight gain might be vague, the lack of negative influence of both SS and ASA in applied dose ranges is confirmed. The existing data often show contradictory results in regard to salicylate influence on weight gain in poultry. Two studies found a beneficial effect of ASA on chicken growth when it was administered with feed at $0.3 \%$ and $0.2 \%(12,23)$ and another study confirmed it for $0.05 \%$ and $0.1 \%(1)$. The same authors stated that the food addition of $0.15 \%$ ASA decreased the weight gain in treated chickens. Several studies show no influence on weight gain in the dose range between $0.0125 \%$ and $0.08 \%(25,27)$. Negative effects were observed by Nakaue et al. (22), who concluded that food supplementation with $0.6 \%$ and $0.9 \%$ ASA decreased weight gain in 4 week old chickens. Murai et al. (21) associated the negative effect of $0.4 \%$ ASA feed addition with polyunsaturated fatty acid deficiency in young chickens.

The highest kidney indices were observed in ASA 200 and SS 200, but as compared to the control group, these results show statistical significance only for ASA. No lesions were found microscopically. In a 3 month study performed on rats a significant increase in kidney weights was observed in male individuals administered with ASA doses of 50,150 and $500 \mathrm{mg} / \mathrm{kg}$ (2). It is difficult to predict if similar phenomenon would appear in chickens after prolonged administration. In the same study (2) a dose-dependent increase in liver weight was observed, but no histological changes were seen. In our study liver weights were lower in all experimental groups treated with either ASA or SS (as compared to the control) but this decrease was not dose dependent and no lesions were found microscopically in either ASA or SS treated groups. It seems that the liver index does not reflect the impact of salicylates on this organ. The previously mentioned study on rats also revealed a decrease in serum globulins. In females, this decrease was significant even in the groups treated with the lowest dose of ASA (50 $\mathrm{mg} / \mathrm{kg}$ ). In the present study, total serum protein content showed significant increase in the group treated with the highest dose of SS in both measurements (day 14 and 20). In the ASA treated animals the highest increase in serum protein was observed only in the ASA 100 group (day 14 and 20). The serum level of albu- mins did not show any significant differences in SS treated groups as compared to the control. In ASA treated groups the highest serum albumin level was observed in the medium dose group. The dose-independent nature of these findings prevents any firm conclusions regarding the background of this increase. We did not observe a decrease in total protein or albumin levels in any group. This means that protein and in particular albumin production was not diminished by the administered salicylates.

In the present study serum ALT levels did not show any significant difference in salicylate treated chickens as compared to the control group. In a study performed on dogs it was found that a dose of $10 \mathrm{mg} / \mathrm{kg}$ ASA administered orally twice a day can significantly affect the levels of serum ALT after 5 days of treatment (15).

No signs of nephrotoxicity or ion imbalances were observed in our study. Blood levels of creatinine, potassium, sodium and calcium did not significantly differ between experimental groups. Although the level of uric acid was slightly increased in the group ASA 200, it still remained within the physiological range (19). Koncicki et al. (16) demonstrated an increase in blood calcium levels in 6-week-old turkeys treated with water containing $0.01 \%$ and $0.05 \%$ ASA. No influence on blood calcium levels was observed in the present study on chickens. In a study performed on dogs treated intravenously with ASA at doses of 7, 70 and $200 \mathrm{mg} / \mathrm{kg}$ in 4 separate injections, a significant decrease in sodium excretion was observed after all applied doses (2). The present study did not show any changes in serum sodium levels, probably indicating higher resistance to sodium imbalances in chickens after ASA administration as compared to dogs. In the study performed by Balog et al. (7) male broiler chickens were given a feed containing $0.2 \%$ ASA for 5 weeks. There was no change in serum calcium, uric acid, total protein and albumin, blood iron and blood urea nitrogen content. Serum alkaline phosphatase and lactate dehydrogenase activity was also unchanged.

During necroscopic examination no gastric erosions or ulcerations were observed in the treated chickens. In one study performed on dogs, gastro-intestinal bleedings were observed in the course of $7 \mathrm{~d}$ treatment with ASA (2). The drug was administered twice a day at doses of 32.5, 65 and $97.5 \mathrm{mg} / \mathrm{kg}$. In another study carried out on dogs atrophic lesions in gastric mucous membranes were observed after 3 months of ASA treatment with the dose of $50 \mathrm{mg} / \mathrm{kg}$ which was the lowest dose applied in this study (2). Kennerman and Polat (15) report gastric and duodenal erosions and submucosal haemorrhages in dogs after 5 and 9 days of oral ASA administration at a dose of $10 \mathrm{mg} / \mathrm{kg}$ twice daily. In rats exposed to 3 month ASA administration in feed, gastro-intestinal lesions were observed after an equivalent of $150 \mathrm{mg} / \mathrm{kg}$ (2). It seems that chickens are much less prone than dogs to develop 
gastro-intestinal symptoms after ASA treatment. This might be due to the drug absorption in the crop and subsequent decrease in the amount entering the glandular stomach.

As no early signs of adverse effects were found, it is concluded that chickens tolerate the conditions of moderate ASA and SS overdose well. The ,no observable adverse effect limit" (NOAEL) could not be established, because even the highest doses did not exert typical signs of toxicity observed in other species at much lower doses. For a more complete safety assessment of salicylates application in poultry medicine comparative studies should be performed on other avian species.

\section{References}

1.Al-Mashhadani E. H., Pitan M. H, Ahmed H. K.: Effect of dietary aspirin on performance and deposition of abdominal fat in broilers. Indian Poultry Sci. 1988, 23, 18-21.

2.Anon.: EMEA/Committee For Veterinary Medicinal Products (CVMP) Acetylsalicylic acid, sodium acetylsalicylate, acetylsalicylic acid dl-lysine and carbasalate calcium EMEA/MRL/99-FINAL November 1999 - Summary Report.

3. Baert K., De Backer P.: Comparative pharmacokinetics of three non-steroidal anti-inflammatory drugs in five bird species. Comp. Physiol. Biochem. C 2003, 134, 25-33.

4. Baert K., De Backer P.: Disposition of sodium salicylate, flunixin and meloxicam after intravenous administration in broiler chickens. J. Vet. Pharmacol. Therap. 2002, 25, 449-453.

5.Baert K., Duchateau L., De Boever S., Cherlet M., De Backer P.: Antipyretic effect of oral sodium salicylate after an intravenous E. coli LPS injection in broiler chickens. Br. Poultry Sci. 2005, 46, 137-143.

6. Balog J. M., Hester P. Y.: Effect of dietary acetylsalicylic acid on eggshell quality. Poultry Sci. 1991, 70, 624-630.

7.Balog J. M., Huff G. R., Rath N. C., Huff W. E.: Effect of dietary aspirin on ascites in broilers raised in a hypobaric chamber. Poultry Sci. 2000, 79, $1101-$ -1105 .

8.Boothe D. M: The analgesic, antipyretic, anti-inflammatory drugs, [in:] H. R. Adams: Veterinary Pharmacology and Therapeutics. Iowa State University Press, Ames 2001, 433-451.

9. Boulianne M., Hunter D. B.: Aspirin: a treatment for sudden death in turkeys Proc. $39^{\text {th }}$ Western Poultry Disease Conf., Sacramento 1990, CA, p. 89-90.

10.Danbury T. C., Weeks C. A., Chambers J. P., Waterman-Pearson A. E., Kestin $S$. C.: Self-selection of the analgesic drug carprofen by lame broilers. Vet. Rec. 1997, 146, 307-311.
11. Gilbert A. B., Mitchell G. G., Davidson M. F., Laughlin K. F., Hugues B. O.: Effect of administering two prostaglandin synthetase inhibitors (indomethacin and aspirin) on egg production in the domestic fowl (Gallus domesticus). Res. Vet. Sci. 1982, 33, 216-220.

12. Glick B.: Research reports. Feedstuffs 1963, 35, 14.

13. Hocking P. M., Robertson G. W., Gentle M. J.: Effects of non-steroidal antiinflammatory drugs on pain-related behaviour in a model of articular pain in the domestic fowl. Res. Vet. Sci. 2005, 78, 69-75.

14.Jouglar J. Y., Benard G.: Indications, modalités pratiques et précautions particulières d'emploie des anti-inflammatoires chez les oiseaux. Rec. Méd. Vét. Special Anti-inflammatoires 1992, 168, 745-747.

15.Kennerman E., Polat U.: Effects of carprofen and acetylsalicylic acid on some biochemical and haemostatic values in dogs. Bull. Vet. Inst. Pulawy 2006, 50, 589-593.

16.Koncicki A., Krasnodębska-Depta A., Souleymane G., Olkowski J.: Badania nad przydatnością terapeutyczną kwasu acetylosalicylowego u indyków. Medycyna Wet. 1999, 55, 826-828.

17.Lascelles B. D. X., McFarland J. M., Swann H.: Guidelines for Safe and Effective Use of NSAIDs in Dogs. Vet. Therapeut. 2005, 6, 237-251.

18. Mathur C. R., Reddy M. S., Rao P. S. P.: Influence of acetylsalicylic acid in layer diet on the performance of pullets during hot weather. Indian Vet. J. 1974, 51, 412-415.

19. Mazurkiewicz M.: Choroby drobiu. Wyd. AR, Wrocław 2005, 691-694.

20.Mc Geown D., Danbury T. C., Waterman-Pearson A. E., Kestin S. C.: Effect of carprofen on lameness in broiler chickens. Vet. Rec. 1999, 144, 668-671.

21. Murai A., Furuse M., Okumura J.: Aspirin toxicity in chicks given diets deficient in linoleic acid. Pharmacol. Biochem. Behav. 1994, 48, 1047-1051.

22. Nakaue H., Weber C., Reed B. L.: The influence of acetylsalicyl acid on growth and some respiratory enzymes in broiler chicks. Proc. Soc. Exp. Biol. Med. 1967, 125, 663-666.

23. Olueyemi J. A., Adebanjo A.: Measures applied to combat thermal stress in poutry under practyicaltopical enviroment Poultry Sci. 1974, 58, 767-773.

24. Proudfoot F. G., Hulan H. W.: Effects of dietary aspirin (acetylsalicylic acid) on the incidence of sudden death syndrome and the general performance of broiler chickens. Canad. J. Anim. Sci. 1983, 63, 469-471

25.Puron D., Santamaria R., Segura J. C.: Effect of sodium bicarbonate, acetylsalicylic and ascorbic acid on broiler performance in a tropical enviroment. J. Appl. Poultry Res. 1994, 3, 141-145

26. Schlossberg A., Bellaiche M., Hanji V., Nyska A., Lublin A., Shemesh M., Shore L., Perk S., Berman E.: The effect of acetylsalicylic acid and cold stress on the susceptibility of broilers to the ascites syndrome. Avian Path. 1996, 25, 581-590.

27. Stilborn H. L., Harris G. C., Bottje W. G., Waldroup P. W.: Ascorbic-acid and acetylsalicylic-acid (aspirin) in the diet of broilers maintained under heat-stress conditions. Poultry Sci. 1988, 67, 1183-1187.

Corresponding author: Hui Yuan, Professor, College of Veterinary Medicine, Hunan Agricultural University (HAU), Changsha, Hunan, 421008, China; Tel: 86-0731-84617269; e-mail: yuanhui7269@yahoo.com.cn 